\title{
ANALISIS PENGARUH INTENSITAS MODAL, LIKUIDITAS, DAN LEVERAGE TERHADAP KONSERVATISME AKUNTANSI
}

\author{
Jessica Salim \\ jessicaasalim@gmail.com \\ Prima Apriwenni \\ prima.apriwenni@kwikkiangie.ac.id \\ Program Studi Akuntansi, Institut Bisnis dan Informatika Kwik Kian Gie, \\ J1. Yos Sudarso Kav 87, Jakarta 14350
}

\begin{abstract}
ABSTRAK
Konservatsime akuntansi merupakan prinsip kehati-hatian dalam pelaporan keuangan dengan melaporkan nilai laba dan aset yang rendah serta nilai biaya dan utang yang tinggi. Penelitian ini bertujuan untuk menguji apakah intensitas modal berpengaruh negatif terhadap konservatisme akuntansi, serta likuiditas dan leverage berpengaruh positif terhadap konservatisme akuntansi. Konservatisme akuntansi merupakan variabel dependen dalam penelitian ini yang diukur dengan akrual non operasional. Variabel independen dalam penelitian ini adalah intensitas modal, likuiditas dan leverage. Sampel dalam penelitian ini adalah perusahaan manufaktur yang terdaftar di Bursa Efek Indonesia pada tahun 2012-2014. Sampel dikumpulkan dengan menggunakan metode purposive sampling dan menghasilkan 74 perusahaan menjadi sampel. Analisis data dilakukan dengan uji asumsi klasik dan pengujian hipotesis dilakukan dengan metode regresi linier berganda dengan menggunakan SPSS. Penelitian ini menyimpulkan bahwa intensitas modal berpengaruh negatif terhadap konservatisme akuntansi. Namun leverage dan likuiditas tidak berdampak positif terhadap konservatisme akuntansi.
\end{abstract}

\section{ABSTRACT}

Accounting conservatsime is a prudent principle in financial reporting by reporting low profit and asset values and high cost and debt value. This study aims to test whether the intensity of capital positively affect accounting conservatism, also liquidity and leverage have a positive effect on accounting conservatism. Accounting conservatism is the dependent variable in this study measured by non-operational accruals. The independent variables in this research are capital intensity, liquidity and leverage. The sample in this study is a manufacturing company listed on the Indonesia Stock Exchange in 2012-2014. Samples were collected by using purposive sampling method and resulted 74 companies to be samples. Data analysis was done by classical assumption test and hypothesis test was done by multiple linear regression method using SPSS. This study concludes that capital intensity negatively affects accounting conservatism. However, leverage and liquidity have no positive impact on accounting conservatism.

Keywords: Accounting Conservatism, Capital Intensity, Liquidity, Leverage.

\section{Pendahuluan}

\section{Latar Belakang}

Laporan keuangan merupakan suatu bentuk penyajian informasi yang digunakan untuk menggambarkan dan menilai kondisi atau kinerja manajemen dan perusahaan dalam kemampuannya untuk menghasilkan penjualan dan laba. Informasi yang disampaikan melalui laporan keuangan ini menjadi salah satu informasi penting bagi pihak-pihak yang berkepentingan dengan 
perusahaan baik pihak internal perusahaan seperti direksi dan karyawan, maupun pihak eksternal seperti investor dan kreditor. Menurut Sari dan Adhariani (2009), laporan keuangan yang dibuat perusahaan haruslah memenuhi tujuan, aturan, dan prinsip-prinsip yang sesuai dengan standar yang berlaku umum agar dapat dipertanggungjawabkan serta bermanfaat dalam pengambilan keputusan bagi pihak yang berkepentingan.

Untuk mewujudkan informasi laba yang berkualitas, maka diperlukan prinsipprinsip akuntansi yang dapat menghasilkan angka-angka relevan dan reliable (Juanda, 2007b). Salah satu prinsip yang berhubungan dengan laporan keuangan dan informasi laba adalah konservatisme akuntansi. Prinsip konservatisme merupakan prinsip kehatihatian terhadap suatu keadaan yang bertujuan untuk menghindari optimisme berlebihan dari pihak perusahaan. Ghozali dan Chariri (2007) menyatakan konservatisme akuntansi berarti harus segera mengakui kerugian, biaya atau utang yang mungkin akan terjadi dan tidak boleh mengakui laba, pendapatan atau aset sebelum benar-benar terjadi. Penerapan prinsip konservatisme akan mengakibatkan nilai kewajiban dan biaya cenderung tinggi dan nilai aset serta pendapatan cenderung rendah.

Fenomena konservatisme akuntansi di Indonesia sendiri dapat dilihat dalam PSAK, yang merupakan prinsip standar akuntansi keuangan yang dikeluarkan IAI sebagai dasar aturan yang wajib diterapkan dalam melakukan pelaporan keuangan untuk semua pihak. Namun masih ada juga beberapa kasus manipulasi data laporan keuangan yang dilakukan oleh perusahaan manufaktur. Kasus manipulasi laporan keuangan di Indonesia yaitu pada perusahaan PT Kimia Farma merupakan kasus rekayasa keuangan dan malpraktek akuntansi, dimana melibatkan pelaporan keuangan yang berawal dari terdeteksi adanya manipulasi seperti manajemen laba (Boediono, 2005). Selain itu juga ada kasus pada PT Indofarma yang terdeteksi terdapat kecurangan dalam penyajian laporan keuangannya.

Kasus PT Kimia Farma merupakan salah satu bentuk manipulasi dengan penyajian laporan keuangan yang overstated yang terjadi di Indonesia. Kasus mark-up laporan keuangan PT Kimia Farma menggelembungkan atau melebihsajikan laba bersih tahunan senilai Rp 32,7 miliar yang merupakan 2,3 persen dari penjualan dan 24,7 persen dari laba bersih PT Kimia Farma (Mamesah et al, 2016). Selain kasus PT Kimia Farma, kasus kecurangan lainnya terjadi pada PT Indofarma yang juga tersangkut kasus skandal overstated dalam penyajian laporan keuangan. Dari hasil penelitian, BAPEPAM menemukan buktibukti di antaranya, barang dalam proses dinilai lebih tinggi dari nilai yang seharusnya dalam penyajian nilai persediaan barang dalam proses sebesar $\mathrm{Rp} 28,87$ miliar. Akibatnya harga pokok penjualan mengalami understated dan laba bersih mengalami overstated dengan nilai yang sama (Mamesah et al, 2016). Kasus seperti ini dapat menyesatkan investor dan stakeholder lainnya. Informasi yang menyesatkan juga akan berdampak pada pengambilan keputusan yang salah. Hal ini juga akan berdampak ke keberlangsungan perusahaan itu sendiri dalam jangka panjang, yang dapat mengakibatkan turunnya nilai saham dan laba perusahaan hingga kebangkrutan. Sehingga diperlukan sebuah mekanisme untuk dapat menguranginya. Kasus - kasus di atas mengindikasikan rendahnya penerapan prinsip konservatisme oleh perusahaan dalam penyusunan laporan keuangannya.

Pihak yang mendukung konservatisme menyatakan bahwa konservatisme menghasilkan laba yang lebih berkualitas karena prinsip ini mencegah perusahaan melakukan tindakan membesar-besarkan laba dan membantu pengguna laporan keuangan dengan menyajikan laba dan aset yang tidak overstate (Fala, 2007). Agar tidak terjadi kasus pelaporan akuntansi yang tidak mencerminkan keadaan keuangan perusahaan sesungguhnya. Di sisi lain, terdapat kritikan atas prinsip ini dan salah satu kritik yang sering muncul adalah prinsip konservatisme ini mempengaruhi hasil dari laporan keuangan. Kiryanto dan Suprianto (2006) menyatakan bahwa jika laporan keuangan dibuat atas dasar metode konservatif hasilnya cenderung bias 
dan tidak mencerminkan keadaan keuangan perusahaan sebenarnya.

Namun terlepas dari pro dan kontra, perkembangan yang terjadi justru menunjukkan bahwa eksistensi praktik konservatisme akuntansi semakin meningkat (Juanda, 2007a, 2007b) dan oleh karena itu penjelasan mengenai konservatisme ini menjadi menarik untuk dibahas karena berhubungan dengan pertimbanganpertimbangan perusahaan dalam menerapkan akuntansi yang konservatif.

Keputusan untuk menggunakan metode yang konservatif atau tidak, dapat ditentukan oleh beberapa faktor. Intensitas modal dapat mempengaruhi perusahaan dalam menerapkan konservatisme akuntansi. Intensitas modal dapat mencerminkan seberapa besar aset yang digunakan untuk menghasilkan pendapatan bagi perusahaan. Semakin tinggi tingkat rasio intensitas modal menunjukkan perusahaan yang padat modal (Parrino dan Kidwell, 2009: 619). Menurut Sinarti dan Mutihatunnisa (2016), Perusahaan yang padat modal cenderung tidak berhati-hati dalam melakukan pelaporan keuangan. Selain itu, perusahaan akan sengaja melebihkan nilai aset dan laba untuk mendapat kepercayaan dan dana dari investor. Hasil penelitian Sinarti dan Mutihatunnisa (2016) dan Agustina et al (2016) menyatakan bahwa intensitas modal berpengaruh negatif terhadap konservatisme akuntansi. Sedangkan Alfian dan Sabeni (2013) serta Susanto dan Ramadhani (2016) dalam hasil penelitiannya menunjukkan bahwa intensitas modal merupakan faktor yang berpengaruh positif terhadap konservatisme akuntansi.

Faktor lainnya yang dapat mempengaruhi konservatisme akuntansi adalah likuiditas. Likuiditas merupakan suatu indikator mengenai kemampuan perusahaan membayar semua kewajiban finansial jangka pendek pada saat jatuh tempo dengan menggunakan aset lancar yang tersedia. Manajer cenderung akan lebih berhati-hati dalam membuat laporan keuangan dengan menggunakan prinsip konservatisme akuntansi apabila perusahaan memiliki likuiditas yang sehat. Hal tersebut terjadi untuk menjaga kredibiltas kondisi keuangan perusahaan. Selain itu, kondisi keuangan perusahaan yang kuat dan kredibel secara otomatis akan membuat biaya politik yang melekat pada perusahaan tersebut semakin besar. Political Cost Hypothesis memprediksikan bahwa perusahaan yang memiliki biaya politik tinggi, manajer akan cenderung memilih untuk menangguhkan laba yang dilaporkan pada periode sekarang ke periode masa mendatang. Tindakan manajer tersebut merupakan bentuk reaksi dari perusahaan dalam menghadapi kemungkinan intervensi oleh pemerintah dan kelompok kepentingan lain yang mungkin dapat mempengaruhi kekayaan perusahaan. Hasil penelitian Nasir et al (2014) menunjukkan bahwa likuiditas berpengaruh positif signifikan terhadap konservatisme akuntansi. Akan tetapi, hasil penelitian Pratanda (2014) menunjukkan bahwa likuiditas tidak berpengaruh terhadap konservatisme pada perusahaan.

Leverage juga dapat mempengaruhi perusahaan dalam menerapkan konservatisme akuntansi. Leverage menunjukkan seberapa besar aset yang digunakan untuk menjalani kegiatan oprasional perusahaan dibiayai oleh hutang dan merupakan indikasi tingkat keamanan dari para pemberi pinjaman. Leverage juga digunakan perusahaan untuk mengukur kondisi kemampuan perusahaan tersebut dalam membayar kewajiban jangka panjangnya, dinilai dari utang yang dibanding kan dengan aset perusahaan tersebut ataupun dengan modal sendiri. Lo (2005) menyatakan jika perusahaan mempunyai hutang yang tinggi, maka kreditor juga mempunyai hak untuk mengetahui dan mengawasi jalannya kegiatan operasional perusahaan. Oleh karena itu, kreditor akan meminta perusahaan untuk menerapkan prinsip kehati-hatian dalam pelaporan laba, sehingga kreditor yakin akan keamanan dan pengembalian dananya. Semakin tinggi nilai leverage suatu perusahaan maka kreditor mempunyai hak lebih besar untuk mengawasi dan mengetahui penyelenggaraan operasi dan akuntansi perusahaan karena kreditor berkepentingan untuk mengamankan dananya. 
Pernyataan Lo (2005) sesusai dengan signaling theory yang menjelaskan bahwa pemberian sinyal dilakukan oleh manajer untuk mengurangi asimetri informasi. Manajer memberikan informasi melalui laporan keuangan bahwa mereka menerapkan kebijakan akuntansi konservatisme yang menghasilkan laba yang lebih berkualitas karena prinsip ini mencegah perusahaan melakukan tindakan membesarbesarkan laba dan membantu pengguna laporan . Sehingga dapat membantu pihak manajemen perusahaan (agent) dan pemegang saham (principal) dalam mengurangi asimetri informasi dengan menghasilkan laporan keuangan yang menyajikan laba akuntansi yang berintegritas. Hasil penelitian Pratanda (2014) menyatakan bahwa leverage berpengaruh positif terhadap konservatisme akuntansi. Hasil penelitian Alfian dan Sabeni (2013) juga menyatakan bahwa leverage merupakan faktor yang berpengaruh signifikan dan positif terhadap konservatisme. Sedangkan menurut peneletian Susanto dan Ramadhani (2016) serta Sinarti dan Mutihatunnisa (2016) menyatakan bahwa leverage tidak berpengaruh terhadap konservatisme akuntansi.

Dengan berbagai latar belakang tersebut, maka peneliti tertarik untuk melakukan penelitian tentang Analisis Pengaruh Intensitas Modal, Likuiditas, dan Leverage Terhadap Konservatisme Akuntansi pada Perusahaan Manufaktur yang Terdaftar di Busa Efek Indonesia Periode 2012-2014.

\section{Tujuan Penelitian \& Manfaat Penelitian}

Tujuan penelitian ini adalah untuk mengetahui pengaruh intensitas modal, likuiditas, leverage terhadap konservatisme akuntansi. Manfaat penelitian ini adalah untuk memberikan informasi dalam mengambil keputusan terkait dengan penyajian laporan keuangan perusahaan sehingga dapat mengelola keuangan perusahaan dengan lebih baik.

\section{Telaah Pustaka \\ Teori Agensi}

Teori agensi merupakan teori yang dapat menjelaskan motif atau tindakan agent untuk menggunakan prinsip konservatisme akuntansi atau tidak dalam membuat laporan keuangan. Teori agensi merupakan teori yang muncul karena adanya konflik kepentingan antara principal dan agent . Principal sebagai pemegang saham sedangkan agent sebagai manajer. Principal mengontrak agent untuk melakukan pengolahan sumber daya yang dimiliki perusahaan, selain itu agent juga berkewajiban untuk mempertanggungjawabkan tugas yang dibebankan kepadanya. Sedangkan principal mempunyai kewajiban untuk memberikan imbalan atas tugas yang telah diberikan kepada agent. Jensen dan Meckling (1976: 308) berpendapat bahwa hubungan keagenan adalah sebagai suatu kontrak antara satu atau lebih pihak yang mempekerjakan pihak lain untuk melakukan suatu jasa untuk kepentingan mereka yang meliputi pendelegasian beberapa kuasa pengambilan keputusan kepada pihak lain tersebut. Menurut Jensen dan Meckling (1976: 308-309), teori agensi ini menyatakan bahwa adanya pemisahan antara principal dan agent akan memunculkan permasalahan agensi karena pihak- pihak tersebut akan selalu berusaha untuk memaksimalkan fungsi utilitasnya masing- masing. Dengan gambaran pihak principal mementingkan hasil keuangan perusahaan atas dasar pengembalian uang investasi di dalam perusahaan, sedangkan pihak agent mementingkan timbal balik seperti kompensasi atau bonus atau tambahan. Perbedaan kepentingan antara principal dan agent dapat menimbulkan permasalahan yang dikenal dengan asimetri informasi. Keadaan asimetri informasi terjadi ketika adanya distribusi informasi yang tidak sama antara principal dan agent. Akibat adanya informasi yang tidak seimbang ini, dapat menimbulkan dua permasalahan yang disebabkan karena adanya kesulitan principal memonitor dan melakukan kontrol terhadap tindakantindakan agent. Teori keagenan digunakan dalam penelitian ini karena membahas tentang konservatisme perusahaan yang dilihat dari laporan keuangan yang bisa mengakibatkan adanya masalah keagenan antara manajemen (agent) dan stakeholder (principal). Penerapan teori ini terdapat pada variabel- variabel independen yang digunakan, yaitu intensitas modal, likuiditas, 
dan leverage yang dapat mempengaruhi konservatisme akuntansi pada perusahaan itu sendiri.

\section{Teori Akuntansi Positif}

Teori akuntansi positif adalah sebuah teori yang berusaha untuk menjelaskan dan memprediksi fenomena tertentu. Teori ini akan mencoba memprediksi tindakan seperti pemilihan kebijakan akuntansi yang diambil perusahaan terhadap standar akuntansi yang baru ( Watts dan Zimmerman, 1990). Menurut Watts dan Zimmerman (1986) ada 3 hipotesis dalam teori akuntansi positif yang meprediksi dan menjelaskan faktor-faktor terentu yang membuat pihak manajemen perusahaan atau agent menerapkan konservatisme akuntansi atau tidak.:

1. Hipotesis Rencana Bonus: Manajer perusahaan dengan rencana bonus yang berdasarkan besar nya laba cenderung memilih prosedur akuntansi dengan laba yang dilaporkan dari periode dimasa depan ke periode saat ini. Seorang manajer atau siapapun itu tentu akan berusaha memberikan laporan pendapatan bersih setinggi mungkin agar mendapatkan bonus yang tinggi. Salah satu caranya adalah dengan memilih dan menentukan kebijakan akuntansi yang tidak konservatif yang bisa meningkatkan laba pada laporan keuangan diperiode tersebut.

2. Hipotesis Kontrak Hutang : Semakin dekat sebuah perusahaan terhadap pelanggaran prinsip akuntansi yang didasari atas sebuah kesepatakan hutang, maka ada kecenderungan semakin besar kemungkinan manajemen perusahaan untuk memilih prosedur akuntansi yang melaporkan laba dari periode masa depan ke periode saat ini atau tidak konservatif.

3. Hipotesis Biaya Politik : Semakin besar biaya politik yang ditanggung oleh perusahaan, maka manajer akan cenderung untuk menggunakan prosedur akuntansi yang konservatif, dengan melaporkan laba pada masa saat ini ke masa mendatang.

\section{Teori Sinyal}

Teori sinyal menjelaskan bahwa pemberian sinyal dilakukan oleh manajer untuk mengurangi asimetri informasi. Asimetri informasi terjadi ketika adanya distribusi informasi yang tidak sama antara principal dan agent. Manajer yang mempunyai motivasi signaling yang melakukan pencatatan secara lebih baik terhadap kinerja perusahaan sehingga laba akuntansi menjadi ukuran kinerja yang lebih informatif (Basu, 1997). Manajer memberikan informasi melalui laporan keuangan bahwa mereka menerapkan kebijakan akuntansi konservatisme yang menghasilkan laba yang lebih berkualitas karena prinsip ini mencegah perusahaan melakukan tindakan membesar-besarkan laba dan membantu pengguna laporan keuangan dengan menyajikan laba dan aktiva yang tidak overstate. Understatement laba dan aktiva bersih yang ditunjukan melalui laporan keuangan merupakan suatu sinyal positif dari manajemen kepada investor dan kreditor bahwa manajemen telah menerapakan akuntansi konservatif untuk menghasilkan laba berkualitas. Investor dan kreditor diharapkan dapat menerima sinyal ini dan menilai perusahaan lebih tinggi.

\section{Konsep Konservatisme}

Definisi formal mengenai konservatisme ada dalam SFAC No. 2 paragraf 95 yaitu bahwa konservatisme merupakan reaksi kehati-hatian terhadap ketidakpastian dan risiko yang melekat pada suatu bisnis. Juanda (2007a) dan Febiani (2012) mendefinisikan konservatisme merupakan prinsip akuntansi yang penerapannya akan menghasilkan angkaangka laba dan aset cenderung rendah, serta angka-angka biaya dan utang cenderung tinggi. Kecenderungan seperti itu terjadi karena konservatisme menganut prinsip memperlambat pengakuan pendapatan serta mempercepat pengakuan biaya. Prinsip ini merupakan cerminan tindakan pesimisis atas ketidakpastian laba atau rugi perusahaan. Agar laporan keuangan dibuat dengan mempertimbangkan ketidakpastian dan risiko bisnis. Kiryanto dan Suprianto (2006 : 5) menyebutkan bahwa terdapat dua jenis laba konservatif, yaitu: (1) ex-ante conservatism 
atau news-independent conservatism dan (2) ex-post conservatism atau news dependent conservatism. Ex-ante conservatism atau news-independent conservatism berkaitan dengan kebijakan-kebijakan yang mengurangi laba secara independen dari kejadian-kejadian ekonomi saat ini, bahkan apabila pengeluaranpengeluaran tersebut berkaitan secara positif dengan harapan aliran kas dimasa yang akan datang. Ex-post conservatism atau news dependent conservatism menggambarkan ketepatan waktu untuk pengakuan laba terhadap bad news dari pada good news. Praktik konservatisme juga bisa dilihat secara nyata dalam standar akuntansi yang berlaku di Indonesia (PSAK). Misalnya, PSAK No. 14 mengenai persediaan, PSAK No. 16 mengenai aktiva tetap, PSAK No. 19 mengenai aktiva tidak berwujud dan PSAK No. 48 mengenai nilai aktiva yang diperoleh kembali.

\section{Intensitas Modal}

Intensitas modal dapat mencerminkan seberapa besar aset yang digunakan untuk menghasilkan pendapatan bagi perusahaan. Ross dan Westerfield dalam Corporate Finance (2012: 54) menyatakan bahwa intensitas modal menggambarkan seberapa besar modal perusahaan dalam bentuk aset, baik aset lancar maupun tidak lancar yang dicerminkan dalam suatu rasio yang menunjukkan perbandingan antara operating assets dengan jumlah penjualan yang diperoleh pada periode tertentu. Rasio intensitas modal berperan penting bagi manajemen perusahaan karena dapat digunakan untuk mengetahui jumlah aset perusahaan yang digunakan dalam rangka menghasilkan pendapatan. Pengukuran rasio intensitas modal atau capital intensity dilakukan dengan membandingkan total aset dengan total penjualan (Ross dan Westerfield 2012: 57). Perusahaan dengan rasio intensitas modal yang tinggi menggambarkan perusahaan yang padat modal (Zmijewski dan Hagerman , 1981: 134).

$\mathrm{Ha}_{1}$ : Intensitas modal berpengaruh negatif terhadap konservatisme akuntansi.

\section{Likuiditas}

Menurut Prihadi (2010: 162) rasio likuiditas bertujuan untuk mengetahui sejauh mana kemampuan perusahaan dalam melunasi kewajiban jangka pendeknya. Peneliti tertarik meneliti likuiditas sebagai variabel yang dapat mempengaruhi konservatsime akuntansi karena likuditas merupakan rasio yang biasa diperhatikan untuk mengukur kondisi aset suatu perusahaan. Rasio likuiditas merupakan suatu indikator mengenai kemampuan perusahaan membayar semua kewajiban finansial jangka pendek pada saat jatuh tempo dengan menggunakan aset lancar yang tersedia. Likuiditas tidak hanya berkenaan dengan keadaan keseluruhan keuangan perusahaan, tetapi juga berkaitan dengan kemampuannya mengubah aset lancar tertentu menjadi uang kas. Menurut Ross dan Westerfield dalam Corporate Finance (2012: 57) pengukuran rasio likuiditas menggunakan current ratio yaitu membandingkan current assets dan current liabilities.

$\mathrm{Ha}_{2}$ : Likuiditas berpengaruh positif terhadap konservatisme akuntansi.

\section{Leverage}

Leverage menunjukkan seberapa besar aset perusahaan dibiayai oleh hutang dan merupakan indikasi tingkat keamanan dari para pemberi pinjaman. Leverage juga menununjukan kemampuan perusahaan dalam membayar kewajiban jangka panjangnya (Ross dan Westerfield, 2012: 50) . Lo (2005: 400-401) menyatakan jika perusahaan mempunyai hutang yang tinggi, maka kreditor juga mempunyai hak untuk mengetahui dan mengawasi jalannya kegiatan operasional perusahaan. Dengan demikian, asimetri informasi antara kreditor dan perusahaan berkurang karena manajer tidak dapat menyembunyikan informasi keuangan yang mungkin akan dimanipulasi atau melebihlebihkan aset yang dimiliki. Oleh karena itu, kreditor akan meminta manajer untuk melakukan pelaporan akuntansi secara konservatif agar perusahaan tidak berlebihan dalam melaporkan hasil usahanya. Untuk pengukuran rasio leverage dihitung dengan cara membandingkan total hutang dengan total aset (Ross dan Westerfield 2012: 57). 
$\mathrm{Ha}_{3}$ : Leverage berpengaruh positif terhadap konservatisme akuntansi.

\section{Metode Penelitian}

\section{Objek Penelitian}

Objek yang akan digunakan dalam penelitian ini merupakan perusahaan manufaktur yang terdaftar di Bursa Efek Indonesia dengan menggunakan data yang akan diteliti adalah data laporan keuangan periode 2012-2014 dengan mempertimbangkan kelengkapan data dan kesesuaian dengan kriteria yang disampaikan.

\section{Variabel Penelitian}

\section{Variabel dependen}

Variabel dependen adalah variabel yang dipengaruhi atau menjadi akibat karena adanya variabel independen. Variabel dependen dalam penelitian ini adalah konservatsime akuntansi. Konservatisme akuntansi merupakan prinsip kehati-hatian dalam pelaporan keuangan. model yang dikembangkan oleh Givoly dan Hayn (2000). Givoly dan Hayn (2000) menggunakan metode pengukuran secara akrual, yaitu dengan menghitung selisih antara laba bersih sebelum depresiasi dan amortisasi dengan arus kas operasi perusahaan. Apabila selisih antara laba bersih dan arus kas operasi bernilai negatif (akrual negatif) maka terjadi penerapan konservatisme dalam laporan keuangan. Model Givoly dan Hayn (2000):

$$
C O N A C C_{I t}=(N I+D e p)_{I t}-C F O_{I t}
$$

Dimana:

$$
\begin{aligned}
\text { CONACC }_{\mathrm{It}}= & \text { Tingkat konservatisme } \\
& \text { akuntansi yang terjadi } \\
& \text { pada perusahaan i pada } \\
& \text { tahun } \mathrm{t}
\end{aligned}
$$

$(\mathrm{NI}+\text { Dep })_{\mathrm{It}}=$ Laba bersih ditambah depresiasi dan amortisasi perusahaan i pada tahun $t$

$\mathrm{CFO}_{\mathrm{It}}=$ Arus kas dari kegiatan operasi perusahaan i pada tahun

\section{Variabel independen}

\section{a. Intensitas Modal}

Intensitas modal menggambarkan seberapa besar modal perusahaan dalam bentuk aset yang dapat digunakan untuk menghasilkan pendapatan dari penjualan produk perusahaan. Rasio intensitas modal yang tinggi menunjukkan bahwa perusahaan tersebut adalah perusahaan yang padat modal. Perhitungan rasio intensitas modal dengan cara membagi total assets dengan total sales perusahaan sesuai dengan rumus dari Ross dan Westerfield dalam Corporate Finance (2012: 54).

\section{b. Likuiditas}

Rasio likuiditas menunjukkan kemampuan perusahaan dalam melunasi kewajiban jangka pendeknya. Dalam penelitian ini dasar pengukuran likuiditas menggunakan Rasio Lancar (Current Ratio) yang sesuai dengan Corporate Finance (Ross dan Westerfield, 2012: 57) yang dapat dihitung dengan membagi current asset dan current liabilities.

\section{c. Leverage}

Leverage (utang) merupakan salah satu sumber dana dari eksternal perusahaan. Leverage ini timbul karena perusahaan dalam operasinya mempergunakan aset dan sumber dana yang berasal dari luar perusahaan sehingga menimbulkan beban tetap bagi perusahaan.Variabel leverage diukur dengan rasio Debt to Asset Ratio yang sesuai dengan penelitian rumus dari Ross dan 
Westerfield dalam Corporate Finance (2012: 57) dimana total liabilities dibagi dengan total assets.

\section{Teknik Pengumpulan Data}

Teknik yang digunakan dalam penelitian ini adalah teknik dokumentasi. Dalam penelitian ini, peneliti menggunakan data yang berasal dari dokumen yang sudah ada. Data yang digunakan adalah data sekunder berupa laporan keuangan perusahaan yang telah diaudit dan dipublikasikan oleh perusahaan-perusahaan manufaktur yang terdaftar di Bursa Efek Indonesia (BEI) selama periode 2012-2014. Peneliti juga memperoleh data mengenai masalah yang diteliti melalui buku, jurnal, thesis, internet, serta perangkat lain yang berkaitan dengan judul penelitian.

\section{Teknik Pengambilan Sampel}

Populasi dalam penelitian ini adalah seluruh perusahaan manufaktur yang terdaftar di Bursa Efek Indonesia dari tahun 2012-2014. Sampel yang dipilih menggunakan metode purposive sampling dan metode slovin yaitu metode pengumpulan sampel yang berdasarkan pertimbangan tertentu atau dapat dikatakan kriteria - kriteria sampel yang akan diambil sudah ditentukan terlebih dahulu.

Adapun pembatasan kriteria dalam pemilihan

populasi adalah sebagai berikut:

1. Perusahaan manufaktur yang terdaftar di BEI pada periode 2012-2014.

2. Perusahaan manufaktur yang menerbitkan laporan keuangan audited per 31 Desember periode 2012-2014.

3. Laporan keuangan dengan mata uang Rupiah

4. Mempunyai data lengkap yang diperlukan untuk diamati, terdiri dari opini audit, kompleksitas perusahaan.

\section{Hasil Dan Pembahasan}

\section{Uji Statistik Deskriptif}

Pada lampiran tabel 2 menunjukkan statistik deskriptif masing-masing variabel penelitian. Berdasarkan tabel 2, hasil analisis dengan menggunakan statistik deskriptif dengan SPSS diketahui bahwa Variabel independen intensitas modal memiliki nilai minimum sebesar 0.0245 , nilai maksimum sebesar 1.8140 , nilai ratarata (mean) sebesar 0.881714 dan standar deviasinya sebesar 0.3238056 . Variabel Ukuran Perusahaan (UP) menunjukkan nilai rata-rata sebesar 0,477 . Nilai terendah ukuran perusahaan sebesar 0,00 , dan nilai tertingginya 1,00 dengan standar deviasi sebesar 0,12230. Variabel independen likuiditas memiliki nilai minimum sebesar 0.0019 sedangkan untuk nilai maksimumnya sebesar 6.7289. Nilai rata-rata (mean) untuk variabel ini sebesar 2.179953 dan standar deviasinya adalah sebesar 1.3777082. Variabel independen leverage memiliki nilai minimum sebesar 0.1282 , nilai maksimumnya sebesar 0.9309 , nilai rata-rata (mean) sebesar 0.447127 dan standar deviasinya sebesar 0.1912104 . Variabel dependen konservatisme akuntansi memiliki nilai minimum sebesar 343626000000, sedangkan nilai maksimumnya sebesar 282991813125. Nilai rata-rata (mean) untuk variabel ini sebesar 17066484708.3099 dan standar deviasinya adalah sebesar 96219034033.1413.

\section{Uji Hipotesis Penelitian}

\section{a. Koefisien Determinasi}

Nilai adjusted $\mathrm{R}^{2}$ diperoleh sebesar 0,034 (lampiran tabel 3). Hal ini berarti bahwa $3,4 \%$ dari konservatisme dapat dijelaskan oleh variabel independen dalam model tersebut sedangkan sisanya sisanya sebesar $96.6 \%$ dipengaruhi atau dijelaskan melalui variabel-variabel lainnya di luar model penelitian peneliti.

\section{b. Uji F}

Nilai F hitung (lampiran tabel 4) sebesar 2.989 dan probabilitias signifikansi ( $p$ value) sebesar 0.033 atau 3.3\%. Dapat 
diketahui bahwa p-value lebih kecil daripada tingkat signifikansi $(\alpha) 0.05$ atau $5 \%$. Artinya, minimal terdapat satu variabel diantara intensitas modal, likuiditas, dan leverage yang berpengaruh terhadap konservatisme akuntansi. Salah satu variabel independen yang mempengaruhi konservatisme akuntansi dapat diuji melalui uji t, yaitu uji secara parsial.

\section{c. Uji t}

Dalam penelitian ini, hasil nilai signifikan probabilitasnya dibagi 2 karena peneliti menggunakan hipotesis satu arah. Dari hasil uji t yang terdapat di dalam tabel 5, didapatkan hasil bahwa variabel intensitas modal memiliki nilai t hitung sebesar -2.593 dan p-value sebesar 0.005 atau $0.5 \%$ (nilai 0.10 dibagi 2). Karena nilai $p$-value lebih kecil daripada tingkat signifikansi $(\alpha)$ 0.05 atau $5 \%$ dan dengan nilai nilai $\mathrm{t}$ hitung nya -2.593 , maka dapat disimpulkan bahwa intensitas modal berpengaruh negatif terhadap konservatisme akuntansi, sehingga dapat disimpulkan bahwa hipotesis $\mathrm{H}_{\mathrm{a}}$ diterima. Variabel likuiditas memiliki nilai t hitung sebesar 0.730 dan $p$-value sebesar 0.2235 atau $23.35 \%$ (nilai 0.467 dibagi 2). Karena nilai $p$-value lebih besar daripada tingkat signifikansi $(\alpha)$ 0.05 atau 5\%, maka dapat disimpulkan bahwa $\mathrm{H}_{02}$ diterima dan $\mathrm{H}_{\mathrm{a} 2}$ ditolak. Hal ini berarti bahwa likuiditas tidak berpengaruh positif terhadap konservatisme akuntansi. Variabel leverage memiliki nilai t hitung sebesar -0.381 dan probabilitias signifikansi ( $p$ value) sebesar 0.352 atau $35.2 \%$ (nilai 0.704 dibagi 2). Nilai p-value lebih besar daripada tingkat signifikansi $(\alpha)$ 0.05 atau $5 \%$. Maka dapat disimpulkan bahwa leverage tidak memiliki pengaruh positif terhadap konservatisme akuntansi. Oleh karena itu dapat disimpulkan bahwa $\mathrm{H}_{03}$ diterima dan $\mathrm{H}_{\mathrm{a} 3}$ ditolak. Hal ini berarti bahwa leverage tidak berpengaruh positif terhadap konservatisme akuntansi.

\section{Uji Asumsi Klasik a. Uji Normalitas}

Uji normalitas data dalam penelitian ini menggunakan uji One Sample KlomogorovSmirnov. Data dikatakan terdistribusi normal jika nilai probabilitas signifikansinya lebih besar dari $\alpha$ yakni 0.05. Berdasarkan output uji normalitas pada lampiran tabel 6 , diketahui bahwa bahwa probabilitas signifikansinya data adalah 0.200 , lebih besar dari 0.05. Dengan demikian, dapat disimpulkan bahwa data dalam penelitian ini terdistribusi normal.

\section{b. Uji Multikolinearitas}

Uji multikolinieritas untuk menguji apakah di dalam model regresi ditemukan adanya korelasi antar variabel bebas. Tolak ukur dari multikolinieritas ini dapat dilihat dari besarnya nilai tolerance dan nilai Variance Inflation Factor (VIF). Nilai cut off yang umum digunakan adalah nilai tolerance 0.10 atau sama dengan VIF diatas 10. Berdasarkan lampiran tabel 5 dapat dilihat bahwa nilai tolerance dari variabel independen intensitas modal, likuiditas, dan leverage berturut-turut adalah 0.999, 0.529, dan 0.530. Nilai-nilai tersebut berada di atas nilai 0.10 . Sedangkan nilai VIF dari intensitas modal, likuiditas, dan leverage berturut-turut adalah 1.001 1.890, dan 1.888. Nilai-nilai VIF tersebut berada di bawah 10. Hal ini menunjukkan bahwa semua variabel independen memiliki nilai tolerance lebih besar dari 0.10 dan nilai VIF lebih kecil dari 10 sehingga dapat disimpulkan bahwa dalam semua model regresi tidak terjadi multikolinieritas.

\section{c. Uji Heteroskedastisitas}

Uji heteroskedastisitas menguji apakah dalam model regresi terjadi ketidaksamaan variance dari residual satu pengamatan ke 
pengamatan yang lain. Uji heteroskedastisitas dilakukan dengan melakukan uji Glejser, yaitu dengan meregresi nilai absolute residual terhadap variabel independen. Dari hasil pengujian diperoleh hasil signifikan masing-masing variabel menunjukkan angka statistik yang tidak signifikan. Berdasarkan lampiran tabel 7, nilai signifikansi dari variabel independen intensitas modal, likuiditas, dan leverage berturut-turut adalah 0.129, 0.129, dan 0.817. Angka-angka tersebut lebih besar dari 0.05 atau $5 \%$ dan hal ini menunjukkan pada model regresi ini tidak terjadi gejala heteroskedastisitas.

\section{d. Uji Autokorelasi}

Uji autokorelasi digunakan menguji apakah dalam sebuah model regresi linear terdapat korelasi antara residual pada periode $\mathrm{t}$ dengan residual pada periode $\mathrm{t}-1$ (sebelumnya). Untuk menguji autokorelasi digunakan Durbin Watson Test. Apabila hasil uji Durbin Watson atau nilai d terletak diantara dU dan (4-dU), maka terima $\mathrm{H}_{0}$ dan tolak $\mathrm{H}_{\mathrm{a}}$, yang berarti tidak ada autokorelasi. Dari hasil pengujian autokorelasi dapat dilihat dari lampiran tabel 3 bahwa nilai Durbin Watson yang diperoleh adalah sebesar 2.004. Nilai ini terletak diantara nilai $\mathrm{dU}=1,7856$ dan nilai 4-dU (4 $1,7856=2.2144)$. Nilai dU diperoleh dari tabel Durbin Watson dengan tingkat signifikansi $0.05, \mathrm{n}=171$, dan $\mathrm{k}=3$. Sehingga dapat disimpulkan terima $\mathrm{H}_{0}$ dan tolak $\mathrm{H}_{\mathrm{a}}$, yang menunjukkan bahwa pada model regresi ini tidak terjadi autokorelasi.

\section{Analisis Regresi Linier Berganda}

Penelitian yang terdiri dari variabel independen intensitas modal, likuiditas, dan leverage diuji menggunakan analisis linier berganda. Lampiran tabel 8 menunjukkan hasil statistik untuk hasil regresi dari persamaan linier penelitian.

$Y=65676983872.688-58122846514.279 X_{I}$ $+5280847086.893 X_{2}-19848402139.677 X_{3}$

Keterangan:

$$
\begin{array}{ll}
Y & =\text { Konservatisme Akuntansi } \\
X_{1} & =\text { Intensitas Modal } \\
X_{2} & =\text { Likuiditas } \\
X_{3} & =\text { Leverage }
\end{array}
$$

Hasil koefisien regresi dari intensitas modal adalah sebesar -58122846514.279 yang berarti bahwa setiap kenaikan intensitas modal sebesar 1\%, maka akan menurunkan nilai konservatisme akuntansi perusahaan sebesar 58,122,846,514.279 rupiah, dengan asumsi variabel independen lainnya bersifat konstan. Koefisien regresi dari likuiditas adalah sebesar 5280847086.893. Hal ini berarti bahwa setiap kenaikan likuiditas sebesar $1 \%$, maka nilai konservatisme akuntansi akan mengalami peningkatan sebesar 5,280,847,086.893 rupiah, dengan asumsi variabel independen lainnya bersifat konstan. Koefisien regresi dari leverage adalah sebesar -19848402139.677 yang berarti bahwa setiap kenaikan leverage yang ditunjukkan melalui rasio leverage (debt ratio) sebesar $1 \%$, maka akan menurunkan nilai konservatisme akuntansi perusahaan sebesar 19,848,402,139.677 rupiah, dengan asumsi variabel independen lainnya bersifat konstan.

\section{Pembahasan}

\section{Pengaruh Intensitas Modal terhadap Konservatisme Akuntansi}

Dalam pengujian hipotesis yang telah dilakukan, hasil penelitian yang pertama menunjukkan bahwa intensitas modal berpengaruh negatif terhadap konservatisme akuntansi. Dengan demikian hipotesis $\mathrm{H}_{\mathrm{a} 1}$ yang menyatakan bahwa intensitas modal berpengaruh negatif terhadap konservatisme akuntansi diterima. Hasil penelitian ini tidak mendukung hasil penelitian Purnama dan Daljono (2013) serta Alfian dan Sabeni (2013), namun mendukung hasil penelitian Sinarti dan Mutihatunnisa (2016) serta Agustina et al. (2016) yang mengungkapkan bahwa intensitas modal berpengaruh negatif terhadap konservatisme akuntansi. Jadi, semakin besar rasio intensitas modal perusahaan, maka laporan keuangan perusahaan semakin tidak konservatif. Peneliti menduga karena rata- 
rata perusahaan manufaktur yang menjadi sampel penelitian adalah perusahaan yang padat modal, sehingga perusahaan cenderung tidak berhati- hati dalam penyajian laporan keuangannya.

Selain itu, perusahaan yang padat modal tentu membutuhkan modal yang besar dari pihak eksternal, dalam hal ini investor yang akan menanamkan investasinya. Perusahaan yang padat modal akan berupaya menyajikan laporan keuangan yang sesuai harapan investor, agar investor percaya akan keamanan dana yang akan ditanamkan. Sehingga demi mencapai tujuan tersebut, manajer akan mengambil kebijakan akuntansi yang menghasilkan laba yang tinggi demi mendapatkan kepercayaan dan modal yang besar dari investor. Jadi laporan keuangan yang dihasilkan cenderung optimis dan tingkat konservatisme akuntansi perusahaan menjadi rendah.

\section{Pengaruh Likuiditas terhadap Konservatisme Akuntansi}

Dalam pengujian hipotesis yang telah dilakukan, hasil penelitian yang kedua menujukkan bahwa likuiditas tidak berpengaruh positif terhadap konservatisme akuntansi. Dengan demikian maka $\mathrm{H}_{\mathrm{a} 2}$ yang menyatakan bahwa likuiditas berpengaruh positif terhadap konservatisme akuntansi ditolak. Hasil penelitian ini tidak mendukung hasil penelitian yang dilakukan oleh Nasir et al. (2014), namun mendukung hasil peneletian dari Purnama dan Daljono (2013), Pratanda (2014), serta Susanto dan Ramadhani (2016) yaitu likuiditas tidak berpengaruh positif terhadap konservatisme akuntansi.

Hasil penelitian ini menunjukan bahwa semakin tinggi tingkat likuiditas perusahaan maka belum tentu menjamin tingginya penerapan konservatisme akuntansi perusahaan. Peneliti menduga bahwa tingginya rasio likuiditas disebabkan oleh perusahaan yang menerapkan kebijakan yang ketat terhadap penjualan kredit sehingga tidak terjadi perubahan yang signifikan terhadap jumlah persediaan. Penyebab lain juga bisa disebabkan oleh kebijakan perusahaan yang memberikan kemudahan piutang sehingga aset lancar terlihat sangat tinggi. Karena dasarnya likuiditas berhubungan dengan kepercayaan kreditor terhadap perusahaan, yang artinya semakin tinggi rasio likuditas maka semakin tinggi juga kepercayaan kreditor terhadap perusahaan. Jadi perusahaan akan tetap berusaha menjaga kinerja perusahaanya agar tetap mendapat kepecayaan dari kreditor dengan menerapkan kebijakan - kebijakan tertentu.

\section{Pengaruh Leverage terhadap Konservatsime Akuntansi}

Dalam pengujian hipotesis yang telah dilakukan hasil penelitian yang ketiga menunjukan bahwa leverage atau utang ternyata tidak memiliki pengaruh positif terhadap konservatisme akuntansi. Dengan demikian maka $\mathrm{H}_{\mathrm{a} 3}$ yang menyatakan bahwa leverage berpengaruh positif terhadap konservatisme akuntansi ditolak. Hasil penelitian ini tidak mendukung hasil penelitian yang dilakukan oleh, Pratanda (2014) namun mendukung hasil penelitian yang dilakukan oleh Susanto dan Ramadhani (2016) serta Purnama dan Daljono (2013) dimana leverage tidak berpengaruh positif terhadap konservatisme akuntansi. Hasil penelitian ini menunjukan bahwa besarnya utang perusahaan tidak menjamin perusahaan akan lebih berhatihati dalam menyusun laporan keuangan dan dalam mengambil keputusan.

Peneliti menduga bahwa kreditor tidak terlalu mengawasi penyelenggaraan operasi dan akuntansi perushaan sehingga memberikan keleluasaan atau kelonggaran bagi manajer dalam perjanjian utangnya mengingat perusahaan tersebut merupakan perusahaan besar atau tidak sedang mengalami kesulitan keuangan yang berarti. Penyebab lain adalah semakin tinggi tingkat utang atau leverage yang dimiliki perusahaan cenderung mendorong manajer untuk menyajikan laporan keuangan yang tidak konservatif. Perusahaan akan memilih metode akuntansi yang meningkatkan laba perusahaan, yang berbanding terbalik dengan konservatisme akuntansi dimana nilai aset, laba, dan pendapatan disajikan secara understate. 


\section{Kesimpulan dan Saran}

\section{Kesimpulan}

Berdasarkan hasil penelitian, intensitas modal terbukti memiliki pengaruh negatif terhadap konservatisme akuntansi, Sedangakan tidak terdapat cukup bukti bahwa likuiditas dan leverage tidak memiliki pengaruh positif terhadap konservatisme akuntansi.

\section{Saran}

Penelitian selanjutnya sebaiknya dapat menggunakan ruang lingkup penelitian selain perusahaan manufaktur, yaitu dapat diperluas dengan menggunakan semua perusahaan di BEI atau dapat menggunakan perusahaan dari sektor perusahaan jasa, sehingga hasil penelitian dapat mewakili seluruh industri. Penelitian ini hanya menggunakan data 3 tahun untuk menghitung tingkat konservatisme. Penelitian selanjutnya dapat menggunakan rentang waktu yang lebih panjang untuk menghasilkan hasil penelitian yang lebih akurat. Di dalam penelitian ini variabel independen hanya dapat menjelaskan $3,4 \%$ variabel dependen, oleh karena itu peneliti selanjutnya dapat menambahkan atau menggunakan variabel independen lain agar dapat lebih banyak menjelaskan variabel dependen.

\section{Daftar Pustaka}

Agustina, Rice, \& Stephen (2016), Analisa Faktor-Faktor yang Mempengaruhi Penerapan Konservatisme Akuntansi pada Perusahaan Manufaktur yang Terdaftar di Bursa Efek Indonesia, Jurnal Akuntansi dan Bisnis (JDAB), Vol. 3, No. 1, Sekolah Tinggi Ilmu Ekonomi Mikroskil.

Alfian, A., \& Sabeni, A. (2013), Analisis Faktor-Faktor yang Berpengaruh Terhadap Pemilihan Konservatisme Akuntansi, Diponegoro Journal of Accounting, Vol. 2, No. 3: $1-10$.

Basu, S. (1997), The Conservatism Principle and The Asymetric Timelines of Earnings,
Journal of

Accounting and Economics 24: 3-37.

Boediono, G. (2005), Kualitas Laba: Studi Pengaruh Mekanisme Corporate Governance dan Dampak Manajemen Laba dengan Menggunakan Analisis Jalur, Simposium Nasional Akuntansi (SNA) VIII Solo: 172-194

Fala, D.A.S. (2007), Pengaruh Konservatisma Akuntansi Terhadap Penilaian Ekuitas Perusahaan Dimoderasi Oleh Good Coorporate Governance, Simposium Nasional Akuntansi X.

FASB. (1980), SFAC No 2. United States of America: FASB.

Febiani, S. (2012), Konservatisme Akuntansi, Corporate Governance, dan Kualitas Laba, Jurnal Ilmiah Mahasiswa Akuntansi, Vol. 1, No. 2: 85-91.

Ghozali, I. (2013), Aplikasi Analisis Multivariate Dengan Program IBM SPSS 21 Update PLS Regresi (ed.7), Semarang: Badan Penerbit Universitas Diponegoro.

Ghozali, I., \& Chariri, A. (2007), Teori Akuntansi (ed.3), Semarang: Badan Penerbit Universitas Diponegoro.

Givoly, D., \& Hayn, C. (2000), The Changing Time Series Properties of Earnings Cash Flows and Accruals: Has Financial Accounting Become More Conservative?, Journal of Accounting \& Economics, 29: 287-320.

Jensen, M.C. \& Meckling, W.H. (1976), Theory of The Firm Management Behavior, Agency, and Ownership Structure. Journal of Financial Economics, 3: 305-360.

Juanda, A. (2007a), Pengaruh Risiko Litigasi dan Tipe Strategi Terhadap Hubungan Antara Konflik Kepentingan dan Konservatisma Akuntansi, Simposium Nasional Akuntansi X.

Juanda, A. (2007b), Perilaku Konservatif Pelaporan Keuangan dan Risiko 
Litigasi pada Perusahaan Go Publik di Indonesia, Naskah Publikasi Penelitian Dasar Keilmuan.

Kiryanto, \& Suprianto, E. (2006), Pengaruh Moderasi Size Terhadap Hubungan Laba Konservatisma Dengan Neraca Konservatisma, Simposium Nasional Akuntansi IX: 1-19.

Lo, E. W. (2005), Pengaruh Tingkat Kesulitan Keuangan Perusahaan Terhadap Konservatisme Akuntansi, Simposium Nasional Akuntansi VIII. Solo: 396440.

Mamesah, M., Saerang, D.P.E., \& Lambey, L. (2016), Faktor - Faktor yang Mempengaruhi Penerapan Konservatisme Akuntansi Pada Perusahaan Asuransi yang Terdaftar di BEI, Bursa Malaysia, dan Singapore Stock Exchange tahun 2010-2014, JDAB, Vol. 5, No. 2 : 237-248.

Nasir, A., Ilham, E., \& Yusniati. (2014), Pengaruh Struktur Kepemilikan Manajerial, Risiko Litigasi, Likuditas, dan Political Cost Terhadap Konservatisme Akuntansi, Jurnal Ekonomi,Vol. 22, No. 2: 93-109.

Parrino, R. \& Kidwell, D.S. (2009), Fundamentals of Corporate Finance, United States of America: John Wiley \& Sons, Inc.

Pratanda, R.S. (2014), Pengaruh Mekanisme Good Corporate Governance, Likuiditas, Profitabilitas, dan Leverage Terhadap Konservatisme Akuntansi, Accounting Analysis Journal, Vol. 3, No. 2: 255-263.

Prihadi, T. (2010), Analisis Laporan Keuangan, PPM Manajemen, Jakarta, Indonesia.
Purnama, W., \& Daljono. (2013), Pengaruh Ukuran Perusahaan, Rasio Leverage, Intensitas Modal, dan Likuiditas Perusahaan Terhadap Konservatisme Perusahaan, Diponegoro Journal of Accounting, Vol. 2, No. 3: 1-11.

Ross, S.A., Westerfield, R.W., \& Jordan, B.D. (2010), Fundamentals of Corporate Finance ( $9^{\text {th }}$ ed.), Boston: McGrawHill.

Sari, C., \& Adhariani, D. (2009), Konservatisme Perusahaan di Indonesia dan Faktor-Faktor yang Mempengaruhinya, Simposium Nasional Akuntansi XII.

Sinarti, \& Mutihatunnisa, S. (2016) Pengaruh Ukuran Perusahaan, Rasio Leverage serta Intensitas Modal terhadap Penerapan Konservatisme Akuntansi pada Seluruh Perusahaan Sektor Non Finansial yang Terdaftar di Bursa Efek Indonesia Tahun 2014: 1-6.

Susanto, B., \& Ramadhani, T. (2016), Faktor Faktor yang Memepengaruhi Konservatisme, Jurnal Bisnis dan Ekonomi: 142-151.

Watts, R.L., \& Zimmerman, J.L. (1986), Positive Accounting Theory, New Jersey: Pretice Hall-Englewood Cliff.

Watts, R.L., \& Zimmerman, J.L. (1990), Positive Accounting Theory: A Ten Year Perspective, The Accounting Review, Vol 65.

Zmijewski, M., \& Hagerman, R. (1981), An Income Strategy Approach to the Positive Theory of Accounting Standard Setting/Choice, Journal of Accounting and Economics, 3:129-149.

$\underline{\text { www.idx.co.id }}$ 


\section{Lampiran}

\section{A. Teknik Pengambilan Sampel}

Tabel 1

Proses Seleksi Sampel Berdasarkan Kriteria

\begin{tabular}{|c|c|}
\hline Kriteria & $\begin{array}{l}\text { Jumlah } \\
\text { Perusahaan }\end{array}$ \\
\hline $\begin{array}{l}\text { Kriteria pemilihan sampel : } \\
\text { Perusahaan manufaktur yang terdaftar di BEI periode 2014-2016 }\end{array}$ & 145 \\
\hline $\begin{array}{l}\text { Jumlah perusahaan tidak sesuai kriteria: } \\
\text { 1. Perusahaan tidak mempublikasikan laporan keuangan } \\
\text { untuk periode yang berakhir pada tanggal } 31 \text { Desember } \\
\text { 2. Data perusahaan tidak lengkap } \\
\text { 3. Perusahaan manufaktur yang menyatakan laporan } \\
\text { keuangan audited dalam mata uang selain rupiah }\end{array}$ & $\begin{array}{l}(3) \\
(23) \\
(28)\end{array}$ \\
\hline Jumlah perusahaan & 91 \\
\hline Jumlah perusahaan yang menjadi sampel dengan metode slovin (5) & 74 \\
\hline Jumlah sampel penelitian & 222 \\
\hline Data outlier & 51 \\
\hline Jumlah sampel penelitian yang dipakai & 127 \\
\hline
\end{tabular}

\section{B. Hasil Pengujian SPSS}

Tabel 2

Statistik Deskriptif

Descriptive Statistics

\begin{tabular}{|l|c|r|r|r|r|}
\hline & $\mathrm{N}$ & \multicolumn{1}{|c|}{ Minimum } & Maximum & \multicolumn{1}{c|}{ Mean } & Std. Deviation \\
\hline INTEN & 171 & .0245 & 1.8140 & .881714 & .3238056 \\
LIKUID & 171 & .0019 & 6.7289 & 2.179953 & 1.3777082 \\
LEV & 171 & .1282 & .9309 & .447127 & .1912104 \\
KONS_AKU & & - & 2829918131 & 17066484708. & 96219034033. \\
$\mathrm{~N}$ & 171 & 3436260000 & 25 & 31 & 141 \\
Valid N & & 00 & & & \\
(listwise) & 171 & & & & \\
\hline
\end{tabular}

Tabel 3

Hasil Uji Autokorelasi dan Koefesien Determinasi

Model Summary ${ }^{b}$ 


\begin{tabular}{|l|r|r|c|r|r|}
\hline $\begin{array}{l}\text { Mode } \\
1\end{array}$ & R & R Square & $\begin{array}{c}\text { Adjusted R } \\
\text { Square }\end{array}$ & $\begin{array}{l}\text { Std. Error of the } \\
\text { Estimate }\end{array}$ & $\begin{array}{l}\text { Durbin- } \\
\text { Watson }\end{array}$ \\
\hline 1 & $.226^{\mathrm{a}}$ & .051 & .034 & $\begin{array}{r}94573781912.5 \\
86\end{array}$ & 2.004 \\
\hline
\end{tabular}

Sumber: Data hasil olahan program SPSS 20

Tabel 4

Uji F

ANOVA $^{\mathrm{a}}$

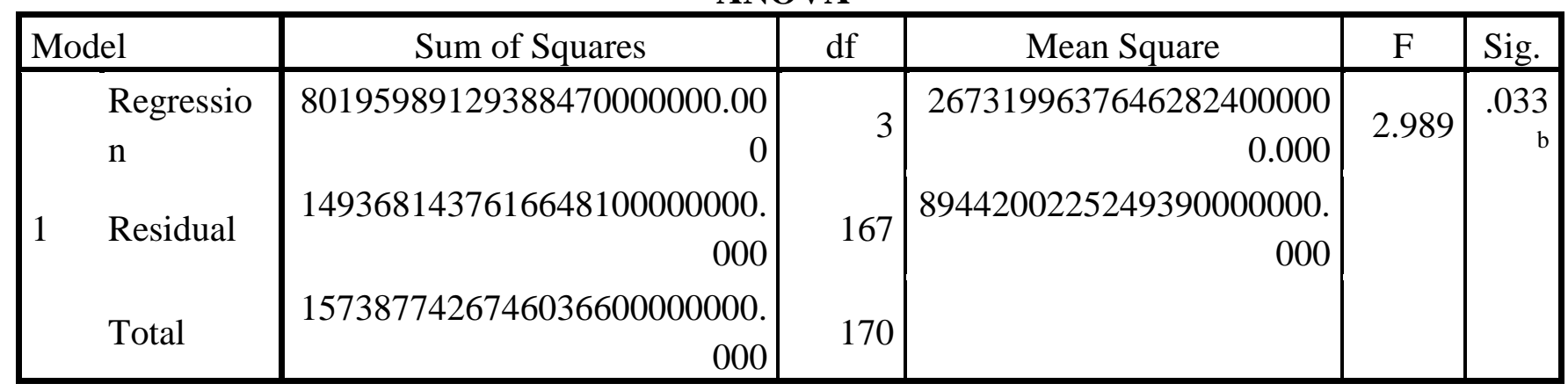

Sumber: Data hasil olahan program SPSS 20

Tabel 5

Uji t dan Uji Multikolinearitas

\begin{tabular}{|c|c|c|c|c|c|c|c|}
\hline \multirow[b]{2}{*}{ Model } & \multicolumn{2}{|c|}{ Unstandardized Coefficients } & \multirow{2}{*}{$\begin{array}{c}\text { Standardized } \\
\text { Coefficients }\end{array}$} & \multirow[b]{2}{*}{$\mathrm{t}$} & \multirow[b]{2}{*}{ Sig. } & \multicolumn{2}{|c|}{$\begin{array}{l}\text { Collinearity } \\
\text { Statistics }\end{array}$} \\
\hline & B & Std. Error & & & & Tolerance & VIF \\
\hline $1 \quad$ (Constant) & 65676983872.688 & 41966810786.146 & & 1.565 & .119 & & \\
\hline INTEN & - & 22414213202.829 & -.196 & $2.593^{-}$ & .010 & .999 & 1.001 \\
\hline LIKUID & 5280847086.893 & 7237703013.731 & .076 & .730 & .467 & .529 & 1.890 \\
\hline LEV & 19848402139.677 & 52128916430.714 & -.039 & -.381 & .704 & .530 & 1.888 \\
\hline
\end{tabular}

Sumber: Data hasil olahan program SPSS 20

Tabel 6

Uji normalitas

One-Sample Kolmogorov-Smirnov Test

\begin{tabular}{|l|r|}
\hline & $\begin{array}{r}\text { Unstandardiz } \\
\text { ed Residual }\end{array}$ \\
\hline $\mathrm{N}$ & 171 \\
Normal Parameters & $\mathrm{a}, \mathrm{b}$ \\
\end{tabular}




\begin{tabular}{|c|c|c|}
\hline \multirow{3}{*}{ 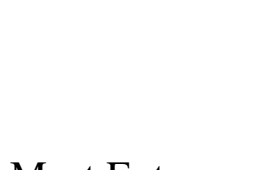 } & Std. & 9373559301 \\
\hline & Deviation & 4.31335000 \\
\hline & Absolute & .082 \\
\hline \multirow{2}{*}{$\begin{array}{l}\text { Most Extreme } \\
\text { Differences }\end{array}$} & Positive & .071 \\
\hline & Negative & -.082 \\
\hline \multicolumn{2}{|c|}{ Kolmogorov-Smirnov Z } & 1.073 \\
\hline \multicolumn{2}{|c|}{ Asymp. Sig. (2-tailed) } & .200 \\
\hline
\end{tabular}

Sumber: Data hasil olahan program SPSS 20

Tabel 7

Uji Heteroskedastisitas

Coefficients $^{\mathrm{a}}$

\begin{tabular}{|c|c|c|c|c|c|}
\hline \multirow[t]{2}{*}{ Model } & \multicolumn{2}{|c|}{ Unstandardized Coefficients } & \multirow{2}{*}{$\begin{array}{c}\begin{array}{c}\text { Standardized } \\
\text { Coefficients }\end{array} \\
\text { Beta }\end{array}$} & \multirow[t]{2}{*}{$\mathrm{t}$} & \multirow[t]{2}{*}{ Sig. } \\
\hline & $\mathrm{B}$ & Std. Error & & & \\
\hline (Constant) & 67497431666 & 28303388044 & & 2.385 & 0.018 \\
\hline INTEN & 23039176551 & 15116663909 & 0.116 & 1.524 & 0.129 \\
\hline LIKUID & -7442475074 & 4881274348 & -0.159 & -1.525 & 0.129 \\
\hline 1 LEV & -8143516552 & 35156947178 & -0.024 & -0.232 & 0.817 \\
\hline
\end{tabular}

a. Dependent Variable: ABSRES

Sumber: Data hasil olahan program SPSS 20

Tabel 8

Analisis Regresi Linier Berganda

\begin{tabular}{|l|r|r|}
\hline \multirow{2}{*}{ Model } & \multicolumn{2}{|c|}{ Unstandardized Coefficients } \\
\cline { 2 - 3 } & \multicolumn{1}{|c|}{$\mathrm{B}$} & \multicolumn{1}{c|}{ Std. Error } \\
\hline 1 (Constant) & 65676983872.688 & 41966810786.146 \\
& & \\
INTEN & -58122846514.279 & 22414213202.829 \\
LIKUID & 5280847086.893 & 7237703013.731 \\
LEV & -19848402139.677 & 52128916430.714 \\
\hline
\end{tabular}

Sumber: Data hasil olahan program SPSS 20

C. Obyek Perusahaan

Tabel 9

Daftar Perusahaan

\begin{tabular}{l|l|l}
1 & ADES & PT Akasha Wira Internatinal Tbk
\end{tabular} 


\begin{tabular}{r|l|l|}
\hline 2 & DLTA & PT Delta Jakarta Tbk \\
\hline 3 & ICBP & PT Indofood CRP Sukses Makmur Tbk \\
\hline 4 & MYOR & PT Mayora Indah Tbk \\
\hline 5 & ROTI & PT Nippon Indosari Corpindo Tbk \\
\hline 7 & PSDN & PT Prashida Aneka Niaga Tbk \\
\hline 8 & STTP & PT Sekar Laut Tbk \\
\hline 9 & ULTJ & PT Ultrajaya Milk Industry \& Trading Company Tbk \\
\hline 10 & CEKA & PT Wilmar Cahaya Indonesia Tbk \\
\hline 11 & RMBA & PT Bentoel Internasional Investama Tbk \\
\hline 12 & GGRM & PT Gudang Garam Tbk \\
\hline 13 & HDTX & PT Panasia Indo Resources Tbk \\
\hline 14 & SSTM & PT Sunson Textile Manufacturer Tbk \\
\hline 15 & MYTX & PT Apac Citra Centertx Tbk \\
\hline 16 & SRSN & PT Indo Acidatama Tbk \\
\hline 17 & BATA & PT Sepatu Bata Tbk \\
\hline 18 & CPIN & PT Charoen Pokphand Indonesia Tbk \\
\hline 19 & JPFA & PT Japfa Comfeed Indonesia Tbk \\
\hline 20 & MAIN & PT Malindo Feedmilll Tbk \\
\hline 21 & TIRT & PT Tirta Nahakam Resources Tbk \\
\hline 22 & ALDO & PT Alkindo Pratama Tbk \\
\hline 23 & KBRI & PT Kertas Basuki Rachmat Tbk \\
\hline 24 & FASW & PT Fajar Surya Wisesa Tbk \\
\hline 25 & SPMA & PT Suparma Tbk \\
\hline 26 & BUDI & PT Budi Starch \& Sweetener \\
\hline 27 & ETWA & PT Eterindo Wahanatama Tbk \\
\hline 28 & DPNS & PT Duta Pertiwi Nusantara Tbk \\
\hline 29 & EKAD & PT Ekadharma International Tbk \\
\hline 30 & AKPI & PT Argha Karya Prima Industry Tbk \\
\hline 31 & AMFG & PT Asahirmas Flat Glass Tbk \\
\hline 32 & APLI & PT Asiaplast Industries Tbk \\
\hline 33 & IGAR & PT Champion Pacific Indonesia Tbk \\
\hline 34 & MLIA & PT Mulia Industrindo Tbk \\
\hline 35 & SIAP & PT Sekawan Inti Pratama Tbk \\
\hline 36 & SIMA & PT Siwani Makmur Tbk \\
\hline 37 & TRST & PT Trias Sentosa Tbk \\
\hline 38 & AKKU & PT Karya Alam Unggul Tbk \\
\hline 39 & YPAS & PT Yanaprima Hastapersada Tbk \\
\hline 40 & INTP & PT Indocement Tunggal Prakasa Tbk \\
\hline 41 & SMCB & PT Holcim Indonesia Tbk \\
\hline 42 & SMGR & PT Semen Indonesia (Persero) Tbk \\
\hline & & \\
\hline 120
\end{tabular}




\begin{tabular}{|c|c|c|}
\hline 43 & ALMI & PT Alumindo Light Metal Industry Tbk \\
\hline 44 & BTON & PT Bentojaya Manunggal Tbk \\
\hline 45 & GDST & PT Gunawan Dianajaya Steel Tbk \\
\hline 46 & LMSH & PT Lionmesh Prima Tbk \\
\hline 47 & JKSW & PT Jakarta Kyoei Steelwork Tbk \\
\hline 48 & JPRS & PT Jaya Pari Steel Tbk \\
\hline 49 & LION & PT Lion Metal Works Tbk \\
\hline 50 & MYRX & PT Hanson Internatinal Tbk \\
\hline 51 & $\mathrm{PICO}$ & PT Pelangi Indah Canindo Tbk \\
\hline 52 & KICI & PT Kedawung Setia Industrial Tbk \\
\hline 53 & $\mathrm{JECC}$ & PT Jembo Cable Company Tbk \\
\hline 54 & $\mathrm{SCCO}$ & PT Supreme Cable Manufacturing \& Commerce (Sucaco) Tbk \\
\hline 55 & VOKS & PT Voksel Electric Tbk \\
\hline 56 & ASII & PT Astra International Tbk \\
\hline 57 & AUTO & PT Astra Otoparts Tbk \\
\hline 58 & IMAS & PT Indomobil Sukses Internatinal Tbk \\
\hline 59 & LPIN & PT Multi Prima Sejahtera Tbk \\
\hline 60 & NIPS & PT Nipress Tbk \\
\hline 61 & PRAS & PT Prima Alloy Steel Universal Tbk \\
\hline 62 & SMSM & PT Selamat Sempurna Tbk \\
\hline 63 & DVLA & PT Darya-Varia Laboratoria Tbk \\
\hline 64 & KLBF & PT Kalbe Farma Tbk \\
\hline 65 & KAEF & PT Kimia Farma (Persero) Tbk \\
\hline 66 & MERK & PT Merek Tbk \\
\hline 67 & SCPI & PT Merek Sharp Dohme Pharma Tbk \\
\hline 68 & PYFA & PT Pyridam Farma Tbk \\
\hline 69 & TSPC & PT Tempo Scan Pasific \\
\hline 70 & TCID & PT Mandom Indonesia Tbk \\
\hline 71 & MRAT & PT Mustika Ratu Tbk \\
\hline 72 & IKAI & PT Intikeramik Alamasri Industri Tbk \\
\hline 73 & KIAS & PT Keramika Indonesia Assosiasi Tbk \\
\hline 74 & TOTO & PT Surya Toto Indonesia Tbk \\
\hline
\end{tabular}

